6

\title{
Bahasa sebagai Alat Komunikasi Politik dalam Rangka Mempertahankan Kekuasaan ${ }^{1}$
}

\author{
Zahri Nasution ${ }^{2}$
}

\section{Ringkasan}

Salah satu sistem isyarat yang paling penting bagi manusia adalah bahasa. Bahasa merupakan kekuatan (language is power) dan sangat berperan dalam mencapai tujuan nasional maupun internasional suatu bangsa. Penggunaan bahasa secara superintensif, termasuk didalamnya penyalahgunaan (abuse) bahasa dengan berbagai aspeknya begitu menonjol dalam dunia politik di Indonesia. Dalam era globalisasi pasar dan informasi dewasa ini, sulitlah membayangkan adanya forum atau panggung komunikasi politis yang bebas dari pengaruh pasar ataupun negara. Produk pertarungan dan rekayasa politik telah menimbulkan suatu struktur kekuasan yang lebih menekankan peran eksekutif yang lebih besar dari pada lembaga legislatif atau yudikatif. Beberapa distorsi bahasa dalam komunikasi politik adalah bahasa sebagai topeng, sebagai proyek lupa, bahasa sebagai representasi, dan bahasa sebagai ideologi. Digunakannya bahasa yang terdistorsi ini antara lain agar kekuasaan yang dimiliki oleh penguasa tetap dapat bertahan. Ketersediaan ruang publik akan dapat efektif untuk memunculkan wacana tandingan apabila diimbangi dengan perubahan struktural dalam masyarakat, terutama menyangkut hubungan antara elit dengan massa.

Katakunci: bahasa, komunikasi politik, kekuasaan

\section{Pendahuluan}

Salah satu sistem isyarat yang paling penting bagi manusia adalah bahasa (Littlejohn, 1996). Dalam bahasa, isyarat terdiri dari pengelompokan sesuatu yang memiliki makna. Suara-suara dikombinasikan ke dalam frasa-frasa, klausa-klausa dan kalimat-kalimat, yang menunjukkan objek. Bahasa sebagai alat komunikasi, pada hakekatnya bersifat netral (Heryanto, 1989), tetapi dapat digunakan sebagai sesuatu yang bersifat baik atau tidak baik. Bahasa menjadi memberikan makna yang salah jika pengertian yang kabur tidak bisa dibatasi penggunaannya, terutama yang sering terjadi antara penguasa yang masyarakatnya. Bahkan dalam segala hal biasanya penguasa akan mengaburkan fakta yang tidak menyenangkan masyarakatnya. Para penguasa, tidak akan

\footnotetext{
${ }^{1}$ Tulisan ini merupakan revisi dari karya ilmiah kuliah Sistem Komunikasi Pedesaan. Penulis mengucapkan terima kasih kepada Bapak Dr. Djuara P. Lubis yang telah memberikan komentar dan koreksi terhadap tulisan ini

2 Peneliti Utama bidang Sosial Ekonomi pada Balai Besar Riset Sosial Ekonomi Kelautan dan Perikanan, Badan Riset Kelautan dan Perikanan, Departemen Kelautan dan Perikanan, sedang menempuh Program Doktor pada Program Studi Sosiologi Pedesaan IPB. Bogor.
} 
pernah mengatakan, "saya bersalah" tapi akan mengatakan, "maaf saya alfa, khilaf" (Lubis, 1989). Oleh karena itu, bahasa merupakan faktor determinan dalam alam berpikir setiap orang, termasuk penguasa yang dapat menggunakan bahasa sebagai alat komunikasi politiknya dalam upaya mempertahankan kekuasaan.

Melalui bahasa juga terlihat keinginan dominasi Barat modern atas manyarakat non-Barat, pada abad lalu, atau bahkan hingga saat ini yang terjadi dimanamana, tidak hanya terjadi di kepulauan Nusantara (Heryanto, 1989), yang tidak lain adalah suatu upaya mempertahankan kekuasaan Barat atas non-Barat. Hal ini terlihat secara nyata pada berbagai kajian tentang kolonialisme, imperialisme, underdevelopment dan dependensia yang banyak memberikan sumbangan pemikiran untuk memahami proses dominasi Barat dan atau Utara di bagian besar dunia ini. Berbagai pemikiran tersebut terlalu mendasarkan analisisnya pada bidang politik-ekonomi, bukan bahasa. Bahkan, kajian-kajian tersebut biasanya membuat generalisasi yang sangat luas, yang dapat merupakan pengaruh bahasa sebagai alat komunikasi politik penguasa untuk mempertahankan kekuasaannya di negara penerima program.

Tulisan ini bertujuan memberikan pemahaman dan mengemukakan bagaimana bahasa memiliki berbagai fungsi dalam kaitannya dengan komunikasi, bahkan tidak jarang digunakan sebagai alat komunikasi politik penguasa untuk mempertahankan kekuasaannya.

\section{Bahasa, Kekuasaan dan Komunikasi Politik}

Bahasa merupakan kekuasaan (language is power) dan sangat berperan dalam mencapai tujuan nasional maupun internasional suatu bangsa. Bahasa membentuk suatu ikatan sosial melalui interaksi dan proses saling mempengaruhi penggunanya (Kurniawan, 2003). Disebutkan pula bahwa penyebaran bahasa (di dunia) menunjukkan bahwa bangsa tersebut telah menguasai (dunia). Terkait dengan bahasa Indonesia, pada jaman penjajahan Jepang, pengerahan segala orang dan tenaga dari bangsa Indonesia dalam sebuah peperangan, membuat bangsa Jepang menggunakan bahasa Indonesia untuk propaganda guna mencapai tujuan dengan cepat. Saat itu, dengan menyisihkan bahasa daerah, penggunaan bahasa Indonesia mencapai masyarakat sampai ke pelosok desa-desa di pegunungan dan pulau-pulau terpencil (Kurniawan, 2003).

Bahasa juga merupakan sarana komunikasi budaya yang penting karena menggambarkan kebudayaan pemakai bahasa tersebut dan membudayakannya melalui penggunaannya (Kurniawan, 2003). Apapun tradisi, apapun kreasi, apapun hasil kebudayaan yang kita miliki, dapat segera punah dan berganti, kecuali satu yaitu bahasa. Bahasa memiliki durasi yang jauh lebih panjang bila dibandingkan dengan produk-produk peradaban lainnya. Dengan bahasalah, suatu bangsa mengemukakan seluruh harapan, obsesi/mimpi, kenyataan, ketakutan, maupun protes-protesnya dalam kehidupan, sehingga bahasa menjadi vital dalam hidup kita. Bahkan kini menjadi senjata karena kita dapat 
menentukan bahkan menguasai seseorang atau sebuah bangsa, hanya dengan berkomunikasi melalui bahasa.

Herbert Marcuse (1898 - 1979) mengatakan bahwa perkembangan bahasa saat ini sudah dibatasi pengertian-pengertian istilahnya dan diabdikan buat kepentingan penguasa dan pengusaha (Kurniawan, 2003). Hal tersebut, antara lain dapat dilihat penggunaan bahasa pada surat kabar. Surat kabar hanya menggunakan kalimat dengan struktur yang mementingkan unsur siapa orang yang menjadi berita. Padahal penyampaian berita baik secara lisan maupun tulisan dalam sebuah wacana memiliki konteks yang ingin dibangun dengan pendengar atau pembacanya karena wacana dipandang sebagai ruang sosial, representasi pengalaman, dan dunia interaksi sosial antar partisipan secara serempak terjadi. Wacana sebagai alat komunikasi tidak terlepas dari kepentingan dan afiliasi pada kelompok atau golongan (Kurniawan, 2003).

Setiap simbol, termasuk suatu proposisi, mengkomunikasikan suatu konsep yaitu suatu idea umum, pola, atau bentuk yang diwujudkan oleh simbol (Littlejohn, 1996). Dalam hal ini, konsep adalah suatu makna yang digunakan bersama di antara komunikator. Tetapi setiap komunikator juga akan mempunyai imaji atau makna pribadi yang mengisi detil-detil gambaran umum, imaji pribadi adalah konsep seseorang tersebut. Oleh karena itu, makna terdiri dari konsepsi individual dan konsep umum. Sebagai contoh, semakin seringnya penggunaan akronim dan eufemisme merupakan gejala sangat mengganggu kelancaran komunikasi di Indonesia saat ini. Padahal sebenarnya, komunikasi harus senantiasa dilakukan secara jernih agar masyarakat bisa menangkap semua fakta dengan jelas. Terlebih-lebih lagi karena kita masih berada dalam tahap menuju moderenisasi, maka sangat penting untuk mengusahakan jangan sampai terjadi ada salah pengertian, salah tangkap diantara anggota masyarakat (Lubis, 1989).

\section{Akronim dan Eufemisme}

Akronim dan eufemisme dapat saja mewakili ketidakdewasaan bangsa kita, yang juga menunjukkan bahwa kita malas menggunakan dua-tiga kata, karena itu kita gunakan satu singkatan yang tidak jelas datangnya dari mana. Dalam komunikasi politik misalnya dari segi penguasa terlihat bahwa kadang-kadang penguasa kita malas melihat kenyataaan yang menyakitkan. Dalam hal ini, penguasa menggunakan ungkapan yang menghaluskan, padahal hal ini dapat mengakibatkan perubahan makna dari yang sebenarnya terjadi. Dari segi penguasa misalnya kenaikan harga BBM menggunakan bahasa "harga disesuaikan dari Rp.2.500,- menjadi Rp.3.500.- per liter" misalnya mengandung sesuatu makna agar tidak terjadi gejolak konflik dalam masyarakat. Namun berbeda halnya, dengan federasi buruh misalnya yang dengan semangatnya menyatakan "lawan" dalam suatu pernyataan aksinya yang memberikan makna bahwa mereka perlu perjuangan untuk mendapatkan sesuatu yang menurut mereka merupakan haknya terhadap para penguasa dan atau pengusaha. 
Penggunaan akronim dapat berdampak memprihatinkan karena ia merusak bahasa dan merusak komunikasi. Karena semua disingkat-singkat, mekanisme berpikir juga dapat terganggu karena kita harus selalu menebak-nebak, sebagai akibat penyingkatan yang dilakukan tidak sistematis. Gejala ini mulai tumbuh sejak masa Demokrasi Terpimpin. Bung Karno yang menabur benih akronim (Lubis, 1989), meskipun sebelumnya memang sudah ada, tapi dialah yang menyuburkannya. Ini ia lakukan untuk agitasi politiknya yang memang mengharuskan orang menggunakan kata-kata yang singkat dan keras agar bisa cepat diterima dan direkam dalam benak pendengarnya. Pidato-pidato atau konsep-konsepnya diakronimkan. Kata-kata Nasakom, Manipol Usdek, dan Gestapu adalah kata-kata yang sampai sekarang tetap diingat orang.

Pada masa Orde Baru, gejala itu makin hebat. Penggunaannya menular sampai ke luar pemerintah, ke segenap lapisan masyarakat. Kita lihat saja betapa banyaknya kata-kata itu kita temukan setiap hari di radio, TV ataupun media cetak. Bahkan lembaga-lembaga non-pemerintah pun gemar mencari-cari singkatan. Jika dikaitkan dengan fungsinya dalam komunikasi dan agitasi politik, penggunaan akronim mungkin bisa dikatakan efektif. Tapi bila itu semua kemudian diakronimkan, justru menjadi tidak komunikatif. Dalam hal ini, akronim dapat merusak kemampuan menyampaikan hal yang sebenarnya dan merusak kemampuan berkomunikasi secara jelas. Dalam hal ini, Santoso (2003) mengemukakan bahwa penggunaan bahasa secara superintensif, termasuk didalamnya penyalahgunaan (abuse) bahasa dengan berbagai aspeknya begitu menonjol dalam dunia politik di Indonesia. Dalam hal ini, bahasa harus dapat menjangkau seluruh lapisan masyarakat, dan bahasa politik sebagai alat komunikasi bertujuan untuk membujuk atau merayu khalayak. Bahasa politik penuh dengan semboyan-semboyan dan kata-kata bersayap serta menghindari penggunaan bahasa yang berkonotasi netral dan objektif (Anwar, 1984 dalam Santoso, 2003).

Anderson (1996) juga mengemukakan bahwa yang luar biasa, karakter bahasa politik Indonesia modern lahir dari kenyataan tak terelakkan bahwa ia adalah ahli waris dari tiga bahasa yang berbeda dan dua tradisi budaya-linguistik yang berbeda pula. Tiga bahasa tersebut adalah Belanda, Jawa dan Melayu revolusioner, sedangkan tradisinya dalah Belanda-Barat dan Jawa. Dalam perpolitikan, tokoh-tokoh politik mempergunakan dan mendayagunakan bahasa bukan saja untuk menyatakan ide, pendapat atau pikirannya, tetapi juga menyembunyikan pikirannya yang mengandung kepentingan-kepentingan yang harus dipertahankan. Namun demikian dalam pelaksanaannya dapat saja berbeda antar rezim pemerintahan atau antar tokoh politik tertentu.

Masing-masing pemerintahan menggunakan bahasa repertoar yang berbedabeda. Pada masa pemerintahan orde lama kata revolusi, antek kapitalis, antek imperialis memberikan arti bahwa pemerintahan Indonesia pada masa itu tidak berpihak kepada sistem kapitalis dan imperialis. Berbeda halnya dengan orde reformasi yang menyuarakan anti $\mathrm{KKN}$, reformasi, dan pemberdayaan DPR. Hal ini menunjukkan bahwa bahasa politik setiap periode pemerintahan 
memiliki karakteristik yang berbeda. Hal ini sesuai dengan pernyataan Tampubolon (1998) yang mengemukakan bahwa dalam setiap era pemerintahan lahir dan berkembang ragam tertentu dalam bahasa Indonesia yang disebut sebagai "ragam politik" (dalam Santoso, 2003).

Komunikasi politik adalah suatu proses komunikasi yang bertujuan untuk mendapatkan dukungan publik bagi seorang kandidat atau kebijaksanaan politik (Setiawan, 1991). Oleh karena itu, tidak heran apabila contoh komunikasi politik yang dimaksud sering kali berupa kampanye pemilihan umum yang dilakukan oleh seseorang kandidat politik. Teori untuk menjelaskan gejala komunikasi politik yang demikian tidak berbeda dengan teori komunikasi pada umumnya. Jadi yang dimaksud dengan komunikasi politik di sini tidak lain adalah upaya komunikasi untuk mempengaruhi proses politik. Kata "politik" pada kata komunikasi untuk menunjukkan bahwa yang kita masuki bukanlah komunikasi sosial biasa. Kata "politik" selalu menyangkut persoalan sumberdaya dan sistem nilai yang tak bernilai harganya dan bagaimana semua itu (hendak) dibagi, diperlakukan, atau ditempatkan dalam suatu negara (Pabottingi, 1989).

Di Indonesia, masalah komunikasi politik yang berkaitan dengan pembangunan dewasa ini lebih menyangkut upaya menghilangkan hambatan di dalam proses komunikasi politik. Hal ini merupakan proses melakukan ekspresi pendapat, sikap, atau perilaku baik perseorangan ataupun kelompok yang bertujuan untuk mempengaruhi pengambilan keputusan mengenai masalah yang berhubungan dengan pemerintahan dan pembangunan. Hal ini bertitik tolak dari pemikiran bahwa hal-hal yang menyangkut masalah pemerintah dan pembangunan yang pada hakekatnya merupakan masalah seluruh anggota masnyarakat Indonesia.

Suatu kehidupan politik atau pemerintahan merupakan suatu produk interaksi atau konflik politik yang terjadi di dalam suatu masnyarakat atau bangsa. Dengan adanya interaksi atau konflik politik itu maka suatu pemerintahan merupakan suatu realitas yang lahir dari resultan berbagai kepentingan. Jadi suatu pemerintahan atau kehidupan politik tidak lahir dari suatu ruang hampa, tetapi dari hiruk-piruk kepentingan yang akhirnya dimenangkan oleh salah satu atau sebagian dari para pendukung kepentingan tertentu. Dengan demikian kehidupan politik selalu berada dalam situasi ketidaksempurnaan. Dalam pemerintahan atau kehidupan politik yang demikian itulah direncanakan program-program pembangunan, yang tentu saja sering kali mengalami hambatan dan ketidaksempurnaan kehidupan politik itu sendiri.

Lahirnya kekuatan Orde Baru bukan merupakan suatu hasil mekanisme politik yang normal, baik antar anggota masnyarakat maupun kekuatan-kekuatan politik. Hal tersebut berakhir dengan suatu kesepakatan untuk memilih kepala pemerintahan. Orde Baru lahir sebagai produk pertikaian dan pertarungan politik yang bersifat fisik, dan tawar-menawar yang kemudian dimenangkan oleh salah satu pihak. Dalam keadaan demikian legimitasi politik diusahakan 
melalui rekayasa bukan produk komunikasi politik yang murni (Setiawan, 1991).

\section{Trauma dan Integrasi Politik}

Kenyataan lain juga menunjukkan bahwa struktur kekuasaaan yang timpang di kalangan komunitas politik berkolerasi pula dengan kemampuan memanfaatkan aset ekonomi hasil pembangunan. Tidak mengherankan bila kemudian timbul persoalan demokrasi ekonomi. Realitas menunjukan bahwa kemampuan ekonomi suatu kelompok sosial sangat berhubugnan dengan adanya akses terhadap kekuasaan atau kemampuan mempengaruhi pengambilan keputusan. Gejala yang demikian bukan merupakan gejala khas di Inodonesia, tetapi memang gejala umum di negara-negara yang sedang berkembang (Setiawan, 1991).

Keseluruhan prilaku politik yang tampak dewasa ini tidak lain merupakan reaksi atau respon berlebihan terhadap trauma politik di masa lampau, pada waktu Indonesia masih menganut sistem pemerintahan parlementer. Pada masa pemerintahan Soekarno, komunikasi politik yag dilakukan oleh kekuatan oposisi dengan amat mudah berpengaruh pada pengambilan keputusan untuk menjatuhkan kabinet penggantian pimpinan ABRI. Di sini yang tampak justru betapa terlalu besarnya pengaruh komunikasi politik terhadap pengambilan keputusan sehingga merupakan kemampuan pemerintahan. Dalam keadaan yang demikian memang tidak dapat tercipta suatu proses komunikasi politik yang berakhir dengan lahirnya saling pengertian dalam bidang kehidupan pemerintahan atau kenegaraan. Akibatnya pemerintah tidak mampu merealisasikan program yang sudah direncanakan. Keadaan ini mencapai klimaks pada waktu konstituante gagal untuk mencapai kata sepakat, untuk menentukan dasar negara sehingga menimbulkan suatu situasi yang dianggap oleh Soekarno dapat membahayakan kehidupan negara. Dalam hal ini, timbul peluang bagi angkatan darat menganjurkan kepada presiden Soekarno perlunya kembali ke Undang-Undang Dasar 1945, yang kemudian memang direalisasikan melalui Dekrit Presiden 5 Juli 1959 (Setiawan, 1991). Dengan kembali ke Undang-Undang Dasar 1945 ini, ABRI yang semula dalam percaturan politik tidak dapat peranan, merasa memiliki kembali peranan politiknya.

\section{Kekuasaan Eksekutif dan Sipil}

Produk pertarungan dan rekayasa politik telah menimbulkan suatu struktur kekuasan yang lebih menekankan peran eksekutif yang lebih besar dari pada lembaga legislatif atau yudikatif. Keadaan ini dapat dipahami mengingat kegagalan di masa penerapan demokrasi liberal antara tahun 1955-1959 telah menimbulkan ketidakstabilan politik, suatu situasi yang tidak memungkinkan pemerintah mampu melaksanakan program-program pembangunan karena ketidakadaaan legitimasi yang lebih kukuh dari masnyarakat yang diperintahnya. Dalam struktur politik yang demikian, tidak heran bila pihak eksekutif selalu berusaha memaksakan kehendaknya kepada institusi yang 
lemah karena lembaga legislatif dan yudikatif secara faktual subordinasi pada lembaga eksekutif dari pada merupakan kekuatan atau kekuasaan penyimbang. Hal ini mengakibatkan arus pengaruh diantara lembaga-lembaga tersebut berjalan dari lembaga eksekutif yang kuat ke lembaga-lembaga legislatif dan yudikatif yang relatif lemah.

Dengan demikian, mekanisme pengambilan keputusan lebih ditentukan oleh lembaga eksekutif dari pada lembaga legislatif dan yudikatif. Keadaan ini menghambat terjadinya mekanisme kontrol eksternal bagi lembaga eksekutif, suatu hal yang sangat dibutuhkan oleh suatu sistem politik. Akibat kurang berperannya lembaga Dewan Perwakilan Rakyat menyalurkan aspirasi masyarakat maka tersumbatlah suatu proses komunikasi politik yang dapat menimbulkan gejolak-gejolak politik seperti peristiwa 15 Januari 1974. Keadaan yang demikian dapat mengoyahkan sendi-sendi pemerintahan karena masyarakat tidak merasa perlu menyampaikan aspirasi mereka kepada lembagalembaga politik yang seharusnya mampu menyalurkan aspirasai tersebut.

Dalam hal hubungan antara kekuatan politik militer dan sipil, karena angkatan bersenjata lebih merupakan suatu kekuatan yang dominan (yang merupakan respon terhadap kertidakstabilan politik zaman pemerintahan sipil yang diwakili oleh pemerintahan Soekarno), maka akibatnya terjadinya arus pengaruh dalam proses komunikasi politik yang juga lebih ditentukan oleh kekuatan militer dari pada kekuatan sipil. Dalam jangka pendek kondisi yang demikian ternyata menguntungkan pemeliharaan stabilitas politik. Namun struktur kekuasaan yang demikian, tidak normal, karena ABRI sebagai suatu kekuatan sosial seharusnya lebih merupakan suatu kekuatan untuk melaksanakan fungsi pertahanan dan keamanan perang.

\section{Mobilitas Politik dan Status-Quo}

Kelebihan pemerintahan yang dijunjang oleh ABRI sebagai kekuatan sosial politik yang mengambil peran dalam pemerintahan, ialah kemampuannya untuk melakukan manajemen konflik, sehingga pertikaian politik bisa diredam sampai pada tingkat tidak mampu menggoyahkan pemerintahan berkat kekuasaannya yang dominan. Kelemahan pemerintahan yang demikian adalah ketidakmampuannya memperlancar arus mobilitas politik karena kekuasaan yang dominan cenderung untuk memilihara status-quo, dan selanjutnya dapat mengakibatkan timbulnya konservatisme di dalam kekuasan karena terlalu lamanya para politisi menduduki suatu jabatan politik. Dalam jangka panjang keadaan yang demikian juga akan memungkinkan terjadinya proses disintegrasi di dalam kekuasan yang besar tersebut karena timbulnya dinamika persaingan antar pusat-pusat kekuasaan yang ada di dalam tubuh ABRI sendiri sebagai akibat kurangnya kompetisi politik yang relatif seimbang dengan kekuatan sosial politik sipil di luar tubuhnya.

Kekuasaan pada dasarnya adalah suatu dinamika yang selalu berubah-ubah besarnya karena adanya proses penimbunan serta proses pengurangan dalam interaksi antar pusat kekuasaan yang ada. Apabila terjadi pergesekan antar 
pusat-pusat kekuasaan karena terhambatnya proses komunikasi politik (akibat terkonsentrasinya kekuasaan pada suatu kekuatan sosial tertentu) keadaan tersebut tidak dapat diketahui dan dideteksi karena tidak cukup informasi terbuka yang tersedia. Indikasi pergesekan tersebut seringkali hanya akan tanpak secara samar-samar bila di antara kekuatan sosial yang sebenarnya tidak potensial secara politik tetapi mampu menimbulkan gejolak atau berekspresi secara vokal. Hal ini mungkin terjadi karena adanya dukungan terselubung dari salah satu pusat kekuasaan.

\section{Demokrasi dan Komunikasi Politik}

Demokarsi merupakan suatu konsep yang dianggap universal, namun pengertian dan pratek demokrasi di berbagai negara dan bangsa mempunyai berbagai muka dan nuansa, yang merupakan produk sejarah masing-masing bangsa. Walaupun demikian ada satu persamaanya, yaitu bahwa pemerintah yang demokratis tersebut hanya dapat diwujudkan dalam suatu nuansa kebebasan atau kemerdekaan. Sementara, kebebasan, menurut pandangan liberal, merupakan suatu hak setiap individu yang perlu dipertahankan karena hanya melalui kebebasan tersebut manusia dapat menyatakan pendapatnya tanpa ada tekanan. Dalam situasi demikian setiap anggota masnyarakat dapat menaggapi suatu pendapat atau gagasan yang ada di dalam masyarakat secara rasional untuk menentukan apakah suatu pendapat atau gagasan dapat diterima atau tidak. Jadi masyarakat dianggap sebagai suatu ajang atau pasar gagasan (market place of idea) dimana masing-masing orang boleh menerima atau menolak suatu pendapat berdasarkan hasil pemikirannya sendiri.

Berbeda dengan pandangan liberal tersebut, masyarakat yang menganut paham komunis menganggap bahwa manusia hanya dapat berkembang apabila kepentingannya disubordinasikan pada kelompok yang dipimpin oleh suatu elit politik yang lebih mampu berpendapat dan berpikir secara rasional. Hanya dengan cara bersedia dipimpin oleh orang yang mempunyai kemampuan di atas rata-rata kebanyakan orang maka keputusan yang diambil adalah keputusan yang tepat, karena bisa membawa manusia ke tingkat yang lebih mulia. Di sini orang yang mempunyai kebebasan berpendapat hanyalah para elit politik, yaitu orang yang dianggap mampu untuk memikirkan masalah kenegaraan. Walaupun pandangan demikian pada saat ini cenderung banyak ditinggalkan, tetapi negara yang menganut paham komunis ini tetap ada.

\section{Demokrasi di Indonesia}

Indonesia sebagai suatu bangsa dan negara yang tidak menganut paham liberal serta tidak menganut paham komunis, menolak formulasi kedua faham tersebut, karena menurut faham Pancasila yang menjadi falsafah bangsa dan negara Indonesia, pada dasarnya manusia adalah makhluk monodualis yang mempunyai baik sisi manusia sebagai makhluk individu maupun sisi manusia sebagai makhluk sosial. Dengan demikian kehadiran kedua sisi tersebut pada diri manusia adalah seimbang. Dalam prakteknya konsep-konsep yang bersifat normatif yaitu pandangan Liberal, Komunis, dan Pancasila, pencerminannya 
tidak dengan sendirinya dapat dengan mudah dilihat dalam masyarakat yang telah memilih salah satu faham tersebut. Dengan demikian bagaimana suatu komunikasi politik dijalankan oleh suatu bangsa tidak dapat hanya dilihat dari falsafah yang melandasi pemikiran, tetapi juga perkembangan konsep demokrasi di dalam suatu negara serta bagaimanan demokrasi tersebut direalisasikan dalam kenyataan.

Demokratis tidak menjamin bahwa suatu pemerintahan mampu mendorong kemajuan secara ekonomis. Hal ini dapat kita lihat di India yang tradisi demokratisnya cukup kuat tetapi perkembangan perekonomiannya tidak kunjung mampu memenuhi kebutuhan bangsanya. Tidak mengherankan bila demokrasi seringkali lebih merupakan slogan politik yang sering digunakan oleh pihak-pihak yang sedang mengalami pertikaian politik. Sering kali suatu rezim atau kelompok penentangnya membela kepentingan politiknya juga dengan alasan demokrasi, walaupun pada prakteknya kemudian pemerintah yang dijalankan tidak lebih demokratis dari rezim yang digantikan.

Demokrasi sebenarnya adalah suatu proses yang tanpa akhir. Dengan memahami demokrasi merupakan suatu proses tanpa akhir maka demokrasi sebenarnya harus diwujudkan melalui suatu penahapan yang dapat direncanakan melalui suatu kebijaksanan atau perencanaan pembangunan atau perubahan sosial. Setiap upaya meningkatkan kualitas demokrasi suatu pemerintahan haruslah melalui suatu penilaian bahwa suatu bangsa atau pemerintahan telah mampu menyelenggarakan suatu pemerintahan yang memenuhi kebuthan dasar masyarakat disertai dengan peningkatan kualitas pemerintahan yang dijalankan melalui cara-cara demokratis.

\section{Sindrom Kekuasaan}

Kekuasaan yang didapat bukan dari hasil komunikasi murni, melainkan sebagian besar adalah produk pertarungan politik, didalamnya sering mengandung suatu sindrom berupa adanya persepsi negatif pada pihak yang memegang kekuasaan terhadap perilaku komunikasi kekuatan-kekuatan sosial di luar dirinya. Hal inilah yang sekarang seringkali perwujudannya timbul berupa berbagai macam larangan mulai dari menyiarkan suatu berita di media massa dan larangan pertunjukan kesenian serta larangan yang bersifat politis lainnya. Apa yang terjadi tersebut sebenarnya dalam kerangka politik sudah merupakan overkilling karena bertitik tolak pada persepsi sepihak. Keadaan yang demikian sudah tentu kurang memberikan keleluasan dalam berekspresi sekalipun mengenai hal yang bukan bidang politik. Di lain pihak, pada kekuasaan yang berasal dari suatu proses komunikasi politik murni, keadaan demikian tidak akan terjadi karena telah mendapat legimitasi psikologis serta adanya keyakinan akan kualitas kepemimpinan yang berasal dari proses pilihan publik. 


\section{Kontrol Media Massa}

Pers sebagai salah satu subsistem komunikasi politik posisinya kurang menguntungkan karena kebebasannya kurang memadai jika adanya lembaga SIT (Surat Izin Tertib), yang sewaktu-waktu dapat dicabut. Dengan digantinya SIT dengan SUIPP (Surat Izin Usaha Penerbitan Press) keadaan tidak banyak berubah. Dengan SUIPP ini apabila press dianggap telah melanggar aturan main, maka dapat dicabut atau dibatalkan SUIPP-nya. Hal ini merupakan hal yang sangat ditakutkan oleh pers. Dalam masalah kebebasan pers ini tampaknya kita tidak mengalami kemajuan, baik sejak zaman penjajahan karena adanya sensor maupun setelah kemerdekaan karena adanya SIT (Surat Izin Terbit) yang kemudian diganti dengan SUIPP yang pada dasarnya sangat bertentangan dengan kebebasan pers.

Alasan mengkaitkan masalah SIT ataupun SUIPP dengan pers yang bertanggung jawab seperti yang sering dinyatakan oleh pemerintah sebenarnya kurang relevan. Dalam hal ini letak tanggung jawab tersebut tidak berarti bahwa pemerintah diberi wewenang untuk menutup suatu perusahaan pers. Tanggung jawab tersebut berada di tangan pers sendiri yang sewaktu-waktu harus berhadapan dengan pengadilan apabila telah melanggar peraturan yang telah ditetapkan untuknya. Lemahnya pers ini mengakibatkan mekanisme kontrol terhadap kekuasaan tidak dapat berjalan efektif. Upaya pemerintah untuk menampung pengaduan masyarakat (seperti kotak pos 5000) hanya efektif sepanjang untuk mengontrol birokrasi. Keadaan demikian memudahkan timbulnya desas-desus di dalam masyarakat yang sangat sulit dikonfirmasikan kebenarannya. Hal ini disebabkan karena informasi telah bercampur baur dengan proses penambahan dan pengurangan yang berlebih-lebihan serta menjadi katup pelepasan atau penyaluran ketidakpuasan masyarakat terhadap jalannya pemerintahan.

\section{Distorsi Bahasa dan Kekuasaan}

Beberapa distorsi bahasa dalam komunikasi politik adalah bahasa sebagai topeng, sebagai proyek lupa, bahasa sebagai representasi, dan bahasa sebagai ideologi. Digunakannya bahasa yang terdistorsi ini antara lain agar kekuasaan yang dimiliki oleh penguasa tetap dapat bertahan. Dalam berbagai kesempatan komunikasi penguasa selalu akan menggunakan bahasa yang terdistorsi dalam mengemukakan sesuatu ide, pikiran ataupun konsep terhadap khalayaknya.

Bahasa sebagai topeng adalah pengungkapkan sesuatu menggunakan bahasa lebih halus jika dibandingkan dengan kondisi yang sebenarnya, yang dikenal sebagai eufemisme. Pabottingi (1989) mengemukakan bahwa eufemisme adalah pelambangan suatu entitas atau pengertian secara lebih halus, pengambarannya bisa lain namun entitas atau pengertiannya sendiri tidak berubah. Dalam hal ini dikemukakan contoh bahwa kata "bagai' atau "seperti" ("bak delima merekah") jelas menunjukan bahwa entitas yang dimaksud tidak berubah. Bandingkan dengan "biar harimau di dalam, kambing juga yang dikeluarkkan". Dengan demikian, terlihat bahwa pengertian yang ditampilkan beda dengan 
pengertian yang sebenarnya ada. Praktek bahasa yang menampilkan suatu lain dari yang dimaksudkan atau lain dari keadaan sebenarnya bisa disebut, "bahasa topeng". Andersoon menyebutkan bahwa praktek yang sama dengan bahasa kramanisasi (Pabottingi, 1989).

Pentingnya masalah "bahasa topeng" segera terlihat begitu kita menghubungkannya dengan komunikasi poltik. Praktek bahasa seperti ini tidak menjadi soal betul jika yang kita persoalkan adalah komunikasi sosial biasa, yang tidak secara telak menyangkut hajad hidup dan hajad nilai orang banyak. Dengan kata lain, jika kita bisa membenarkan praktek bahasa topeng dalam komunikasi sosial biasa (seperti jika seseorang marah sekali, namun tetap berkata-kata lembut), sulit bagi kita untuk membenarkannya dalam komunikasi politik. Pabottingi (1989) mencontohkan bahwa spanduk "hormatilah pejalan kaki" yang sering kali terbentang di jalan-jalan raya, misalnya, adalah bahasa topeng yang sebetulnya sudah mencapai tingkat politis. Pejalan kaki adalah rakyat yang jumlah puluhan juta. Dan pejalan kaki yang jumlahnya demikian besar itu memang perlu disantuni, diberi tempat-tempat untuk berjalan dan menyeberang dengan aman. Tapi terlepas dari bunyi spanduk itu, kita menyaksikan bahwa disebagian besar jalan-jalan dibangun hanya bagi pengendara motor dan mobil. Tempat-tempat penyeberangan tidak dilengkapi dengan lampu lalu lintas dan disiplin dalam pemakai jalan umum tidak ditanamkan. Kita tidak melihat adanya ofensif usaha pemerintah untuk sungguh-sungguh menyantuni rakyatnya yang berjalan kaki karena terpaksa atau demi kesehatan. Dengan kata lain, kita berhenti pada slogan. Ketika berhenti pada slogan itulah "hormatilah pejalan kaki" menjadi "bahasa topeng". Karena kata-kata itu tidak sungguh-sungguh dimaksudkan apalagi jika realitasnya justru berlawanan. Ia hanya menjadi "topeng".

Kemudian, ihwal lupa adalah kodrat manusia. Di sini kita membicarakan lupa sebagai sesuatu yang dimanipulasikan. Demi kejelasan argumen, kita terlebih dahulu harus meluruskan arti lupa. Pabottingi (1989) mengemukakan bahwa dalam keadaan normal dan sadar, lupa bukan berarti tidak ingat. Dalam keadaan normal dan sadar, lupa berarti ingat yang lain. Dengan memahami ini, kita lalu dapat memaklumi bahwa lupa dapat diciptakan dan direncanakan. Manusia adalah makhluk yang penuh keterbatasan, yang perhatiannya amat mudah dialihkan. Lupa dapat diciptakan dan direncanakan bukan hanya atas satu orang, melainkan atas puluhan bahkan ratusan orang. Dengan mengalihkan perhatian seseorang atau ratusan juta orang, kita membuat mereka lupa. Lebih parah lagi, lupa ini dapat diperpanjang selama yang dkehendaki oleh manipulator lupa.

Sebagai contoh, Pabottingi (1989) mengemukakan bahwa iklan rokok dan merokok selalu dikaitkan dengan yang wah, yang bergengsi, yang trendy. Merokok dikaitkan dengan mobil balap, wajah tampan, kuda perkasa, gadis cantik bertubuh ramping. Di Indonesia, rokok dan merokok banyak dihubungkan dengan imaji-imaji kejantanan (pria punya selera!) atau dengan kreatifitas (creative generation). Tak satupun iklan rokok di tanah air yang 
menghubungkan atau mengingatkan kebiasaan merokok dengan bahayanya bagi kesehatan. Dengan kata lain, semua iklan rokok disini memanipulasi praktek iklan mereka sehingga para perokok atau calon perokok tidak ingat bahwa merokok punya dampak buruk bagi kesehatan.

Bahasa sebagai proyek lupa juga berlaku pada hal-hal yang jauh lebih penting bagi hajad hidup orang banyak. Misalnya, kita dapat terjerumus ke dalam proyek lupa sejarah. Ini terjadi manakala orang menulis sejarah dengan sengaja menghilangkan atau mengecilkan arti suatu peristiwa, jejak, dan tokoh tertentu yang seharusnya tidak dapat dilupakan begitu saja karena jasa-jasanya pada negara dan bangsa. Pabottingi (1989) mengemukakan bahwa beberapa tahun lalu, Jepang pernah diprotes keras oleh negara-negara Asia tetanggannya. Hal ini terjadi karena buku pelajaran sejarah resmi untuk sekolah di Jepang tak memuat sedikitpun informasi tentang praktek bengis serdadu Jepang di negaranegara tetangga selama Perang Dunia II. Negara-negara tadi berhak untuk cemas jika generasi muda Jepang melupakan praktek biadab yang pernah dilakukan bangsanya kepada negara-negara tetangga tersebut. Sebab lupa dalam hal ini adalah lisensi bagi pengulangan kebiadaban. Itulah sebabnya bahwa perjuangan manusia melawan kekuasaan adalah perjuangan ingat melawan lupa.

Disamping itu, distorsi bahasa sebagai representasi terjadi jika kita menggambarkan sesuatu tidak sebagaimana mestinya (Pabottingi, 1989). Dalam komunikasi politik, penggambaran tidak sebagaimana mestinya ini juga merupakan tindakan yang berbahaya. Sebagai contoh misalnya, gambaran jelek juga pernah berlaku atas kaum komunis dan bangsa-bangsa Asia pada umumnya. Dalam sepuluh tahun terakhir, di Amerika banyak tersebar gambaran buruk tentang Jepang, dan mungkin juga di Jepang tentang Amerika. Menjelang Perang Dunia II kita menjumpai ramainya penggambaran Jepang sebagai fasis dan negara-negara sekutu sebagai kekuatan pembela demokrasi. Seperti di kupas tajam oleh Bung Karno dalam kasus Jepang-fasis dan Sekutudemokratis, semua penggambaran berkaitan langsung dengan pertarungan kepentingan dan perebutan sumberdaya. Penggambaran jelek adalah senjata simbolik untuk menghancurkan lawan, dengan jalan membangkitkan kebencian atas mereka serta mengesahkan pembantaian atau penghancuran.

Distorsi bahasa sebagai ideologi adalah distorsi yang yang didasarkan dua alasan. Pertama, setiap ideologi pada dasarnya memang sudah bersipat distortif, dan kedua, dirtorsi ideologis sangat pandai menggunakan ketiga jenis distorsi lainnya. Secara garis besar dapat dikemukakan dua perspektif politik yang cenderung menyebarkan distorsi ideologis, yaitu; (1) perspektif yang mengidentikkan kegiatan politik sebagai privilese sekelompok orang; dan (2) perspektif yang semata-mata menekankan tujuan tertinggi suatu sistem politik. Perspektif yang mengidentikkan kegiatan politik sebagai privilese sekelompok orang mungkin adalah perspektif ideologis tertua yang dikenal sejarah. Tapi meskipun ia paling tua, ia pula yang senantiasa muncul dalam praktek politik dari masa ke masa. Perspektif inilah yang berlaku ketika Plato, misalnya, 
hendak merekayasa bibit unggul untuk jadi penguasa, atau ketika Soeriokoesoemo, seperti Plato, menekankan "hak orang bijaksana" untuk memerintah. Perspektif yang menekankan tujuan suatu sistem politik tidak terlalu mempersoalkan apa yang sesungguhnya dikehendaki oleh lingkungan politik (rakyat) dan bagaimana sistem nilai mereka. Pendukungnya lebih banyak di dalam utopia dari pada di alam kenyataan. Begitulah pada Hegel ketika mengkultuskan negara. Begitu juga yang berlaku pada Marx ketika ia bermimpi tentang suatu masyarakat tanpa kelas atau ketika dia mencanangkan diktumnya bahwa masalahnya bukanlah bagaimana menafsirkan dunia, melainkan bagaimana mengubahnya.

Para pendukung kedua perspektif tersebut ditandai oleh distorsi-distorsi komunikasi politik yang relatif paralel. Kedua-keduanya ahli dalih dalam menggunakan "bahasa topeng" misalnya dalam menemukan begitu banyak dalih untuk menyepak saingan politiknya dari panggung politik. Keduanya ahli dalam proyek lupa sejarah yang menutup sama sekali kemungkinan adanya legitimasi buat lahirnya perspektif politik yang lain. Dalam hal memotret jelek saingan politik, mereka juga sangat terlatih. Tapi selain itu, pada keduanya kita bisa melihat pola-pola distorsi bahasa yang semuanya bertujuan untuk membenarkan dirinya sendiri.

Menurut Lubis (1989), akarnya ada dalam kebudayaan feodal, yang memandang "ratu" atau penguasa sebagai kekuatan sakral yang tidak mungkin salah. Namun demikian, tidak semua etnik di Indonesia mempunyai konsep kekuasaan seperti itu. Di Minangkabau, Bali atau Batak, nilai-nilai demokrasi justeru banyak ditemui. Atau di Jawa, sebelum tumbuhnya kekuasaan feodalisme yang sangat menindas, tetap ada unsur-unsur demokrasi. Di lain pihak, dalam nilai-nilai kebudayaan yang dominan, sikap menghamba kepada raja memang telah ada sejak lama, dan penguasapun bersikap menuntut rakyat menghamba kepada mereka.

Sebagai contoh misalnya, pada zaman pendudukan Jepang, kita menggunakan kata "berkenan untuk Gubernur Militer". Penguasa berganti, istilah yang digunakan tetap saja menetap, bahkan digunakan sampai sekarang. Hal ini menunjukan sikap tertentu penguasa dalam menggunakan bahasa sebagai alat komunikasi yang searah kepada rakyatnya. Bahkan dalam bentuk karya sastra, dalam skala global antara penguasa (imperialis) selalu berusaha mengintegrasikan kebudayaannya terhadap masyarakat di negara bekas jajahannya. Meskipun demikian, hal tersebut sebenarnya tidak pernah dicapai dan tidak pernah mampu membentuk dasar kebudayaan pribumi (Ashcroft et al., 2003).

\section{Ruang Publik dan Komunikasi Politik}

Bagian ini sebagian besar diambil dan disarikan dari tulisan karya Hardiman (2006) dengan judul Ruang Publik Politis: Komunikasi Politis dalam Masyarakat Majemuk. Pemahaman demokrasi di negara-negara yang sedang melangsungkan transisi dari otoritarianisme menuju demokrasi seperti negara 
kita bersifat minimal. Demokrasi dimengerti sebagai pemilihan umum yang berlangsung fair. Demokrasi minimalis ini mengabaikan proses di antara pemilihan umum yang satu dan pemilihan umum yang lain. Namun, jika bertolak dari konsep demokrasi itu sendiri, kita tak dapat berhenti pada sikap minimalis. Dikemukakan pula bahwa demokrasi tidak sekadar dipahami formalistis, ia harus memberikan kemungkinan kepada warga negara mengungkapkan opini mereka secara publik. Ruang atau, katakanlah, panggung tempat warga negara dapat menyatakan opini, kepentingan, serta kebutuhan mereka secara diskursif dan bebas tekanan itu merupakan inti ide ruang publik politis.

Dalam masyarakat majemuk dewasa ini, suatu identifikasi "kedaulatan rakyat" dengan "perwakilan rakyat" dalam Dewan Perwakilan Rakyat (DPR)/Majelis Permusyawaratan Rakyat (MPR) menjadi semakin sulit karena sistem politik "hanyalah" salah satu subsistem di antara subsistem lain di dalam sebuah masyarakat kompleks. Karena itu, konsep kedaulatan rakyat harus ditafsirkan secara baru (Hardiman, 2006). Dijelaskan pula bahwa kedaulatan rakyat adalah "totalitas bentuk" dan "isi komunikasi" tentang persoalan-persoalan publik yang berlangsung, baik di dalam sistem politik (eksekutif, legislatif, dan yudikatif) maupun di dalam masyarakat luas. Jika interpretasi ini dapat diterima, ruang publik politis yang berfungsi baik dan kedaulatan rakyat adalah satu dan sama. Konsep ruang publik politis merupakan pemahaman baru atas konsep kedaulatan rakyat agar konsep ini dapat diterapkan di dalam masyarakat kompleks di era globalisasi ini.

Dalam karya awalnya, Strukturwandel der Oeffentlichkeit (Perubahan Struktur Ruang Publik), Juergen Habermas menjelaskan ruang publik politis sebagai kondisi-kondisi komunikasi yang memungkinkan warga negara membentuk opini dan kehendak bersama secara diskursif. Pertanyaannya sekarang, kondisikondisi manakah yang diacu oleh Habermas? Pertama, partisipasi dalam komunikasi politis itu hanya mungkin jika kita menggunakan bahasa yang sama dengan semantik dan logika yang konsisten digunakan. Semua warga negara yang mampu berkomunikasi dapat berpartisipasi di dalam ruang publik politis itu. Kedua, semua partisipan dalam ruang publik politis memiliki peluang yang sama untuk mencapai suatu konsensus yang fair dan memperlakukan mitra komunikasinya sebagai pribadi otonom yang mampu bertanggung jawab dan bukanlah sebagai alat yang dipakai untuk tujuan-tujuan di luar diri mereka. Kemudian, Ketiga, harus ada aturan bersama yang melindungi proses komunikasi dari represi dan diskriminasi sehingga partisipan dapat memastikan bahwa konsensus dicapai hanya lewat argumen yang lebih baik. Singkatnya, ruang publik politis harus "inklusif", "egaliter", dan "bebas tekanan". Kita dapat menambahkan ciri-ciri lain: pluralisme, multikulturalisme, toleransi, dan seterusnya. Ciri ini sesuai dengan isi konsep kepublikan itu sendiri, yaitu dapat dimasuki oleh siapa pun.

Dalam era globalisasi pasar dan informasi dewasa ini, sulitlah membayangkan adanya forum atau panggung komunikasi politis yang bebas dari pengaruh 
pasar ataupun negara. Kebanyakan seminar, diskusi publik, demonstrasi, dan seterusnya didanai, difasilitasi, dan diformat oleh kekuatan finansial besar, entah kuasa bisnis, partai, atau organisasi internasional dan seterusnya. Hampir tak ada lagi lokus yang netral dari pengaruh ekonomi dan politik (Hardiman, 2006). Jika demikian, ruang publik politis harus dimengerti secara "normatif": ruang itu berada tidak hanya di dalam forum resmi, melainkan di mana saja warga negara bertemu dan berkumpul mendiskusikan tema yang relevan untuk masyarakat secara bebas dari intervensi kekuatan-kekuatan di luar pertemuan itu. Kita menemukan ruang publik politis, misalnya, dalam gerakan protes, dalam aksi advokasi, dalam forum perjuangan hak-hak asasi manusia, dalam perbincangan politis interaktif di televisi atau radio, dalam percakapan keprihatinan di warung-warung, dan seterusnya.

Hardiman (2006) mengemukakan bahwa pada masa rezim Soeharto, negara mengintervensi pembentukan opini publik dengan alasan pemeliharaan stabilitas nasional, mengawasi media massa secara ketat demi keamanan nasional, menstigma para oposan, dan merintangi pembentukan spontan kelompok-kelompok politis. Pemerintah saat itu membenarkan politik represifnya dengan alasan bahwa negara sudah diperlengkapi dengan DPR/MPR untuk kanalisasi aspirasi publik, sementara lembaga perwakilan ini berada di bawah dominasi eksekutif. Negara Orde Baru adalah sebuah sistem administrasi otoriter yang merintangi pembentukan ruang publik politis dengan menciptakan publik semu yang bertindak seolah-olah mewakili volonte generale.

Dalam negara hukum demokratis, ruang publik politis berfungsi sebagai sistem alarm dengan sensor peka yang menjangkau seluruh masyarakat (Hardiman, 2006). Ruang publik berfungsi baik secara politis jika secara "transparan" memantulkan kembali persoalan yang dihadapi langsung oleh yang terkena. Transparansi itu hanya mungkin jika ruang publik tersebut otonom di hadapan kuasa birokratis dan kuasa bisnis. Namun, itu tak berarti bahwa para pelaku ruang publik menyerah saja pada imperatif pasar dan birokrasi. Tanpa memenuhi tuntutan normatifnya, ruang publik hanya akan menjadi "ekstensi" pasar dan negara belaka. Di dalam negara hukum demokratis, media massa merupakan kekuatan keempat setelah eksekutif, legislatif, dan yudikatif. Media massa dapat berfungsi secara benar dalam ruang publik politis jika otonom tidak hanya dari negara dan pasar, melainkan juga dari para aktor ruang publik itu sendiri. Ia harus mampu menetralkan pengaruh uang dan kekuasaan yang dapat memanipulasi ruang publik politis. Ia memang tak mungkin lepas sama sekali dari para aktor tipe kedua, tetapi ia dapat dan seharusnya menangkap dan melontarkan suara-suara yang mencerminkan kepublikan seluas-luasnya.

Dalam ruang publik politis, masyarakat sipil melangsungkan diskursus publik dalam berbagai bentuk dan isi. Suara-suara dalam ruang publik politis berciri anarkis dan tak terstruktur. Hardiman (2006) membayangkan adanya dua macam filter dalam prosedur demokratis: filter dalam ruang publik politis itu sendiri dan filter sistem politik. Suatu opini memiliki kualitas sebagai opini 
publik jika lolos dari filter ruang publik. Publik pembaca dan pendengar bisa saja dimanipulasi ataupun diintimidasi untuk menerima sebuah opini, tetapi opini macam itu tetap akan dipersoalkan autentisitasnya selama publik tetap mendapat akses untuk menguji kesahihannya (Hardiman, 2006).

Tidak dapat disangkal bahwa kekuasaan sosial dan kerap juga kekuasaan politis ikut bermain menentukan proses penyaringan opini dalam ruang publik politis itu. Tidak hanya ada figur-figur berpengaruh, melainkan juga lembagalembaga yang disegani dan memiliki kekuasaan. Namun, sekali lagi, selama peranan kekuasaan ini dapat diperiksa secara publik, opini yang dipengaruhi oleh kekuasaan itu tidak imun terhadap kritik publik. Hardiman (2006) mengemukakan bahwa jika publik itu cerdas, akan terjadi seleksi rasional di antara argumen-argumen dengan kemenangan argumen yang lebih baik, yang lalu mendapat kualitas sebagai opini publik. Karena komunikasi publik mengikuti norma argumen yang lebih baik, kualitas suara akan lebih menentukan daripada kuantitasnya.

\section{Upaya Mempertahankan Kekuasaan}

Pada praktiknya, rezim penguasa dapat mempertahankan kekuasaan melalui 4 cara, yakni dengan cara memaksa, "membeli", memobilisasi, dan memanipulasi (Pascarina, 2005). Memaksa dilakukan dengan media militer yang digunakan sebagai alat negara untuk menekan masyarakat agar tunduk dan patuh pada kehendak negara; "membeli" dilakukan dengan membangun konglomerasi para pemilik modal yang dibantu oleh negara; memobilisasi dilakukan dengan strategi korporatisme negara; dan memanipulasi dilakukan dengan menggunakan wacana. Keempat strategi berikut ini diterapkan oleh penguasa untuk mempertahankan kekuasaannya.

Pada masa Orde Baru misalnya, keempat strategi ini dilakukan oleh rezim Suharto untuk menjustifikasi, mempertahankan, dan melanggengkan kekuasaannya. Karenanya, tidaklah mengherankan bila negara kemudian menjadi pusat dari seluruh praktik kepemerintahan. Ideologi pembangunan yang dipakai sebagai dasar berjalannya negara didefinisikan dan diinterpretasikan oleh rezim penguasa sebagai pertumbuhan ekonomi yang digandengkan dengan pendekatan keamanan. Peran militer menjadi sangat penting untuk mempertahankan stabilitas nasional sehingga negara membentuk sejumlah lembaga represif untuk melakukan pemantauan terhadap kehidupan sosial politik masyarakat sekaligus mengamankan kekuasaan pusat.

Dalam bidang ekonomi, pemerintah Orde Baru sejak awal menyandarkan legitimasinya sebagian besar pada kemampuan untuk memajukan kesejahteraan sosial dan ekonomi rakyat Indonesia yang sangat besar jumlahnya. Karena itu, ideologi pembangunan diidentikan dengan pertumbuhan ekonomi yang mengarah pada modernisasi. Negara memfasilitasi tumbuh dan berkembangnya kaum pemilik modal melalui pinjaman-pinjaman luar negeri untuk mendorong proses industrialisasi di Indonesia sehingga lahirlah pola konglomerasi di kalangan pemilik modal. 
Sementara untuk meredam sikap kritis dari kelompok-kelompok masyarakat, digunakan mekanisme korporatisme negara di mana negara mengendalikan kepentingan-kepentingan yang berkembang dalam masyarakat dengan menerapkan prinsip pluralisme terbatas. Dalam korporatisme negara, keberadaan organisasi masyarakat diatur, ditentukan, bahkan diciptakan oleh pemerintah sendiri. Aspek pengendalian menjadi penting bagi kelangsungan perkembangan organisasi masyarakat tersebut. Pengendalian dan intervensi pemerintah umumnya bersifat exclusionary, yaitu mengucilkan atau tidak mengakui keberadaan organisasi masyarakat yang kepentingannya dianggap bertentangan atau membahayakan kepentingan pemerintah. Dengan demikian, partisipasi masyarakat dalam politik umumnya diarahkan untuk aktivitasaktivitas yang ditentukan oleh rezim dan organisasi-organisasi yang didukungnya.

Partisipasi politik yang otonom sulit untuk berkembang karena ditentukan oleh mentalitas dari penguasa, yang umumnya didominasi oleh elit-elit militer, birokrat, dan politisi yang terkooptasi atau partai-partai politik pro-rezim. Dengan demikian, dapat dikatakan bahwa model partisipasi yang diterapkan adalah partisipasi yang terkontrol, baik dalam hal ruang partisipasinya maupun sarana partisipasinya. Upaya pelanggengan kekuasaan Orde Baru juga dilakukan melalui strategi manipulasi wacana. Melalui strategi ini, negara menggunakan bahasa sebagai media untuk melakukan transfer ideologi dan relasi kekuasaan. Negara mengontrol pendefinisian dan pemaknaan terhadap seluruh produk berbahasa. Masyarakat tidak memiliki cukup akses untuk memperoleh informasi seputar penentuan kebijakan. Masyarakat pun tidak banyak diberi peluang untuk memperoleh informasi dari sumber-sumber alternatif di luar sumber-sumber yang dikontrol penguasa.

Kebijakan mengenai informasi apa yang bisa dan perlu dikonsumsi oleh publik, secara dominan ditentukan oleh rezim penguasa. Dalam era reformasi pascaOrde Baru, upaya pelanggengan kekuasaan masih tetap dilakukan oleh rezim penguasa. Hanya saja strategi yang dipakai sekarang adalah strategi manipulasi wacana karena sejalan dengan perubahan konfigurasi kekuasaan terjadi pula perubahan dalam pilar-pilar penopang Orde Baru. Peran militer semakin berkurang sejalan dengan meluasnya tuntutan penghapusan peran politik militer, partisipasi masyarakat mulai meluas, sumber daya finansial negara menyusut akibat KKN. Menyusutnya kekuatan ketiga strategi tersebut menempatkan wacana menjadi alat mempertahankan kekuasaan yang relatif halus.

Pertarungan wacana menjadi alat untuk merefleksikan pertarungan kepentingan-kepentingan politik dalam relasi kekuasaan. Dominasi elit dan kapital dalam membangun wacana merupakan kecenderungan yang harus diwaspadai dari perluasan ruang publik. Bila kecenderungan ini tidak diantisipasi, maka perluasan ruang publik akan menjadi sia-sia karena masyarakat luas justru menjadi pihak yang tidak memiliki akses terhadap ruang publik tersebut sehingga ruang publik yang terbentuk bukan merupakan ruang 
publik yang otonom. Ketersediaan ruang publik menjadi lebih efektif untuk memunculkan wacana tandingan apabila diimbangi dengan perubahan struktural dalam masyarakat, terutama menyangkut hubungan antara elit dengan massa. Desain hubungan elit dan massa lebih diarahkan pada pola interaksi yang transaksionis dan bukan instruksionis. Karena itu, penggunaan bahasa, baik dari segi struktur maupun substansinya, harus membuka peluang bagi seluruh pihak untuk menguji validitas klaim yang diajukan pihak lain. Perkembangan media massa dapat dimanfaatkan sebagai media melakukan pendidikan politik yang kritis bagi masyarakat.

\section{Penutup}

Bahasa merupakan kekuasaan (language is power) dan sangat berperan dalam mencapai tujuan nasional maupun internasional suatu bangsa. Bahasa membentuk suatu ikatan sosial melalui interaksi dan proses saling mempengaruhi penggunanya. Bahasa sebagai alat komunikasi, pada hakekatnya bersifat netral, tetapi dalam komunikasi, bahasa dapat digunakan sebagai sesuatu yang bersifat baik atau tidak baik dalam penggunaannya oleh pihak tertentu. Dalam komunikasi massa, bahasa dapat berperanan dalam mengadakan ke arah perbaikan, melalui usaha tidak bersikap memihak kepada penguasa, sehingga dapat membawa arah perubahan dan menjadikan bahasa berfungsi komunikatif dan demokratis.

Penggunaan bahasa secara superintensif, termasuk didalamnya penyalahgunaan (abuse) bahasa dengan berbagai aspeknya begitu menonjol dalam dunia politik di Indonesia. Oleh karena itu diperlukan ruang publik politis yang "inklusif", "egaliter", dan "bebas tekanan", dengan tambahan ciri lainnya, misalnya: pluralisme, multikulturalisme, toleransi, dan seterusnya. Namun demikian, dalam era globalisasi pasar dan informasi dewasa ini, sulitlah membayangkan adanya forum atau panggung komunikasi politis yang bebas dari pengaruh pasar ataupun negara. Produk pertarungan dan rekayasa politik telah menimbulkan suatu struktur kekuasan yang lebih menekankan peran eksekutif yang lebih besar dari pada lembaga legislatif atau yudikatif.

Beberapa distorsi bahasa dalam komunikasi politik adalah bahasa sebagai topeng, sebagai proyek lupa, bahasa sebagai representasi, dan bahasa sebagai ideologi. Digunakannya bahasa yang terdistorsi ini antara lain agar kekuasaan yang dimiliki oleh penguasa tetap dapat bertahan. Ketersediaan ruang publik akan dapat efektif untuk memunculkan wacana tandingan apabila diimbangi dengan perubahan struktural dalam masyarakat, terutama menyangkut hubungan antara elit dengan massa. Namun demikian, perluasan ruang publik akan menjadi sia-sia jika masyarakat luas justru menjadi pihak yang tidak memiliki akses terhadap ruang publik tersebut. Dalam kondisi demikian ruang publik yang terbentuk bukan merupakan ruang publik yang otonom, tetapi lebih kepada akibat adanya dominasi elit dan kapital, dan politisi yang terkooptasi atau partai-partai politik yang pro-rezim penguasa. 


\section{Daftar Pustaka}

Ashcroft, B., G. Griffiths. dan H. Tiffin., 2003. Menelanjangi Kuasa Bahasa: Teori dan Praktik Sastra Poskolonial. Alih Bahasa: Fati Soewandi \& Agus Mokamat. Penerbit Qalam. Yogyakarta. 393 p.

Anderson, Benedict. R.OG., 1996. Bahasa Politik Indonesia. dalam Latif, Yudi dan Idi Subandy Ibrahim (Editor). Bahasa dan Kekuasaan; Politik Wacana di Panggung Orde Baru. hal; 124-153. Penerbit Mizan. Bandung.

Hardiman, F. Budi., 2006. Ruang Publik Politis: Komunikasi Politis dalam Masyarakat Majemuk. Artikel Komunikasi. DUNIAESAI.COM. (diakses tgl. 16 Juni 2007).

Heryanto, Ariel., 1989. Berjangkitnya Bahasa-Bangsa di Indonesia. Majalah Pemikiran Sosial Ekonomi. Prisma No. 1 Tahun XVIII, 1989. Halaman 3-16. LP3ES. Jakarta.

Kurniawan, R. Okta. 2003. Bahasa: Sebuah Kekuatan. Warta Departemen Pertahanan Republik Indonesia. Vol. 15 No. 1 Mei - Juni 2003. Warta Dephan Online. Biro Humas Setjen Dephan. Jakarta. (diakses tgl 16 Juni 2007).

Littlejohn, Stephen W., 1996. Theories of Human Communication. BKU Ilmu Komunikasi. Pascasarjana Universitas Padjadjaran. Bandung. 625 p.

Lubis, Mochtar., 1989. Media Massa dan Bahasa yang Terus Terang. Majalah Pemikiran Sosial Ekonomi. Prisma No. 1 Tahun XVIII, 1989. Halaman 47-51. LP3ES. Jakarta.

Pabotinggi, Mochtar., 1991. Komunikasi Politik Dalam Transformasi Ilmu Politik. Majalah Pemikiran Sosial Ekonomi. Prisma No. 6 Tahun XX, Juni 1991. Halaman 13-26. LP3ES. Jakarta.

Oetomo, Dede., 1989. Bahasa Indonesia dan Kelas Menengah Indonesia. Majalah Pemikiran Sosial Ekonomi. Prisma No. 1 Tahun XVIII, 1989. Halaman 17-29. LP3ES. Jakarta.

Paskarina, Caroline. 2005. Dolema Ruang Publik Dalam Demokratisasi. Bujet Edisi III/07 Oktober - Nopember 2005. Bandung Institute of Governance Studies. (diakses tgl. 16 Juni 2007).

Santoso, Anang., 2003. Bahasa Politik Pasca Orde Baru. Penerbit Wedatama Widya Sastra. Jakarta. 273 p.

Setiawan, Bambang., 1991. Komunikasi Politik Dalam Pelaksanaan Pembangunan. Majalah Pemikiran Sosial Ekonomi. Prisma No. 6 Tahun XX, Juni 1991. Halaman 3-12. LP3ES. Jakarta. 
